\title{
Hubungan Status Gizi dan Aktivitas Bermain melalui Keterampilan Gerak Dasar Anak Taman Kanak-Kanak
}

\author{
Mardiah Wulandari ${ }^{凶}$, Moch. Asmawi2 ${ }^{2}$, Karnadi ${ }^{3}$ \\ Pendidikan Anak Usia Dini, Universitas Negeri Jakarta \\ DOI: $\underline{10.31004 / o b s e s i . v 5 i 2.965}$
}

\begin{abstract}
Abstrak
Permasalahan penelitian ini yaitu kurang optimalnya keterampilan gerak dasar anak TK di Kecamatan Nanggalo Kota Padang yang diikuti dengan kecenderungan rendahnya status gizi dan aktivitas bermain. Tujuan penelitian adalah untuk melihat hubungan status gizi dan aktivitas bermain baik secara independen maupun dependen dengan keterampilan gerak dasar anak TK. Metode penelitian ini adalah kuantitatif asosiatif model korelasi multipel. Teknik pengumpulan data menggunakan angket dan tes. Hasil penelitian menunjukkan bahwa terdapat hubungan positif antara status gizi dengan keterampilan gerak dasar anak TK yaitu $12,45 \%$. Hubungan positif antara aktivitas bermain dengan keterampilan gerak dasar anak TK yaitu $26,21 \%$. Adanya hubungan positif antara status gizi dan aktivitas bermain secara bersama-sama dengan keterampilan gerak dasar anak TK yaitu 47,89\%. Keterampilan gerak dasar anak berkembang dengan optimal jika lembaga memberikan fasilitas yang memadai.
\end{abstract}

Kata Kunci: gerak dasar; bermain; anak usia dini.

\begin{abstract}
The problem of this research is the lack of optimal basic movement skills of kindergarten children in Nanggalo District, Padang City, followed by a tendency to have low nutritional status and playing activities. The research objective was to see the relationship between nutritional status and play activities both independently and dependently with the basic movement skills of kindergarten children. This research method is quantitative associative multiple correlation model. Data collection techniques using questionnaires and tests. The results showed that there was a positive relationship between nutritional status and basic movement skills of kindergarten children, namely $12.45 \%$. The positive relationship between play activities and basic movement skills of kindergarten children is $26.21 \%$. There is a positive relationship between nutritional status and play activities together with basic movement skills of kindergarten children, namely $47.89 \%$. Basic movement skills of children develop optimally if the institution provides adequate facilities.
\end{abstract}

Keywords: basic motion; played; early childhood.

Copyright (c) 2021 Mardiah Wulandari, Moch. Asmawi, Karnadi

$\triangle$ Corresponding author :

Email Address: mardiahwulandari05@gmail.com (Jakarta, Indonesia)

Received 14 December 2020, Accepted 31 December 2020, Published 5 January 2021 


\section{PENDAHULUAN}

Pendidikan TK merupakan lembaga pendidikan prasekolah bagi anak yang berusia 36 tahun. Pendidikan Taman Kanak-kanak adalah lembaga pendidikan prasekolah sebelum memasuki lembaga pendidikan Sekolah Dasar (SD) yang melibatkan anak didik yang berusia $4 \mathrm{~s} / \mathrm{d} 6$ tahun, dengan lama pendidikan berkisar $1 \mathrm{~s} / \mathrm{d} 2$ tahun (Herrera \& Owrutsky, 2020). Pendidikan anak usia dini merupakan upaya pembinaan yang ditujukan kepada anak sejak lahir sampai dengan usia enam tahun yang dilakukan melalui pemberian rangsangan pendidikan untuk membantu pertumbuhan dan perkembangan jasmani dan rohani agar anak memiliki kesiapan dalam memasuki pendidikan lebih lanjut (Ayuni \& Setiawati, 2019; Chatterjee, D. S., Biswas, S. J., \& Adhikary, 2014; Rozalena \& Kristiawan, 2017; Surya, 2017).

Pertumbuhan jasmani yang dapat dikembangkan adalah keterampilan gerak dasar. Aktivitas jasmani yang dilakukan manusia merupakan keterampilan gerak (Wijayanto \& Muhammad, 2014). Hal ini sependapat dengan Anisa Herdiyana (2016) bahwa Pertumbuhan jasmani bertujuan untuk mengembangkan keterampilan gerak dasar, kebugaran jasmani, pola hidup sehat, berpikir kritis, sosial, moral serta pengenalan lingkungan bersih melalui aktivitas jasmani. Keterampilan gerak dasar adalah pola gerakan yang melibatkan bagian tubuh seperti kaki, lengan, badan dan kepala, dan termasuk keterampilan seperti berjalan, melompat, menangkap, melempar, memukul dan menyeimbangkan (Lillard et al., 2013; Agustini et al., 2016). Untuk itu keterampilan gerak dasar sangat penting dan perlu dikembangkan pada usia dini, agar anak dapat melakukan aktivitas fisik dan terhindar dari obesitas pada masa kanakkanak hingga dewasa (Lubans et al., 2010).

Affirm achievement of a sufficient fundamental motor skills level by the end of the preschool period is an important premise for the later participation of children in many sports activities. Gerakan dasar yang diperlukan untuk anak-anak 3-8 tahun sebagai pendahulu yang lebih khusus, keterampilan kompleks digunakan dalam bermain, permainan, olahraga, tari, senam, pendidikan luar ruangan dan fisik dan kegiatan rekreasi (Alderman et al., 1999). Bhutta et al., (2013) dan Chen et al., (2009) menjelaskan bahwa "the basic elements of motion that shape motor skills are strength, agility, balance, and coordination. Motor skills are the foundation for early childhood". Elemen dasar gerak yang membentuk keterampilan motorik adalah kekuatan, kelincahan, keseimbangan, dan koordinasi. Keterampilan gerakan dasar merupakan bagian penting untuk perkembangan motorik seumur hidup sehingga dianggap sebagai pondasi penting untuk keterampilan olahraga dikemudian hari (Marinšek \& Denac, 2020; Obrusnikova \& Cavalier, 2018).

Penelitian yang dilakukan Hands \& Martin (2003) bahwa keterampilan gerak dasar anak kurang terlatih pada anak usia dini, karena perkembangan kebiasaan buruk dan takut anak terluka atau cedera. Keterampilan gerak anak usia dini terlihat pada pola permainan yang dilakukan oleh guru. Aktivitas bermain yang dilakukan kurang menarik dan pemilihan permainan yang lebih mendominasi ke anak laki-laki dari pada anak perempuan. Hal ini disebabkan karena minimnya pengetahuan guru tentang keterampilan gerak dasar anak. Penelitian yang dilakukan Fitria \& Rohita (2019) menunjukkan bahwa pembelajaran dalam mengembangkan keterampilan gerak dasar anak minim, yang disebabkan karena keterbatasan lapangan dan keterbatasan kemampuan guru. Selain itu dilaporkan bahwa anakanak usia dini tidak memenuhi tingkat fisik yang direkomendasikan. Ditemukan anak-anak tidak aktif secara fisik dan tidak mempelajari gerak dasar sehingga ketika dewasa keterampilan gerak dasar tidak berkembang dengan baik ketika anak dewasa nantinya (Johnson et al., 2019).

Berdasarkan observasi yang lakukan pada beberapa TK di Kota Padang (2018) yaitu: TK Pembangunan Laboratorium UNP Padang, TK Pertiwi 1 Padang, TK Bhayangkara 2 Padang, dan TK Adabiah Padang masih ditemukan masalah bahwa sebagian anak TK belum memiliki keterampilan gerak dasar yang optimal. Beberapa fenomena yang teramati: masih ada anak-anak yang belum mampu berlari dengan keseimbangan tubuh yang baik. Artinya, mereka belum memiliki keterampilan gerak dasar lokomotor yang optimal, masih banyak 
anak-anak yang kurang tepat melemparkan bola ke sasaran atau kurang mampu menangkap bola dengan baik. Hal ini menunjukkan bahwa mereka belum memiliki keterampilan aspek gerak dasar non-lokomotor dengan baik. Faktor yang diduga lebih dominan sebagai penyebab cenderung rendahnya keterampilan gerak dasar anak TK tersebut adalah Status Gizi dan Aktivitas Bermain.

Berdasarkan penelitian yang dilakukan Gonçalves et al., (2020) bahwa "Nutrition is the main pillar of health and well-being throughout the life cycle". Nutrisi merupakan pilar utama dari kesehatan dan kesejahteraan sepanjang siklus hidup. Early childhood is often called the golden age that is an active individual with rapid growth and development so the nutritional needs must be met and balanced (Herrera \& Owrutsky, 2020). Keterampilan gerak individu dipengaruhi oleh status gizi individu itu sendiri. Dimana jika pertumbuhan dan perkembangan itu tidak dibarengi oleh asupan gizi yang cukup, maka akan berpengaruh juga pada gerak anak. Apabila individu dengan status gizi kurang atau buruk salah satunya akan mengalami hambatan pertumbuhan fisik yang secara langsung mempengaruhi tingkat keterampilan gerak umum individu tersebut (Reinke et al., 2020). Hal ini akan berpengaruh pada kurangnya keterampilan gerak yang dimiliki anak. Agar anak tumbuh dan berkembang baik maka diperlukan dukungan status gizi yang cukup, baik kuantitas maupun kualitasnya. Status gizi merupakan salah satu indikator terpenting kesehatan, keterampilan fisik atau keterampilan gerak dan untuk menunjang pertumbuhan anak secara normal (Baykal et al., n.d.) Status gizi yang diharapkan adalah dalam kategori baik. Anak usia dini sering disebut zaman keemasan, karena individu akan mengalami pertumbuhan dan perkembangan yang sangat cepat sehingga dibutuhkan nutrisi yang seimbang.

Selain itu, faktor aktivitas bermain mempengaruhi keterampilan gerak dasar anak. Bermain merupakan salah satu aktivitas anak usia TK. Aktivitas bermain merupakan kegiatan yang menyenangkan bagi anak TK. Melalui aktivitas bermain, anak melakukan berbagai pengalaman gerak (Alderman et al., 1999). Dengan demikian, melalui aktivitas bermain akan terjadi peningkatan keterampilan gerak dan berbagai aspek penting lainnya. Bermain adalah dunia anak, tiada hari tanpa bermain bagi anak, dan lewat bermain pula segala aspek perkembangan anak dapat ditingkatkan, baik perkembangan fisik atau keterampilan gerak dasar, pemikiran, sosial, emosional, dan moral anak. belief that play mirrors development and that, as the child grows and matures, the appearance, function, and implications of play may change (Grantham-McGregor et al., 2014). Berdasarkan penelitian Jhony \& Putra (2019) bahwa dengan adanya aktivitas bermain dapat membantu mengembangkan keterampilan gerak dasar anak. Aktivitas bermain yang dapat dilakukan adalah permainan olahraga. Seperti: melempar dan menangkap bola, menggiring bola dengan melewati beberapa kerucut (cone), dan lain-lain. Aktivitas bermain yang dilakukan dengan menarik dan menyenangkan bagi anak.

Penelitian yang dilakukan Setiawati et al., (2020) tentang hubungan status gizi dengan pertumbuhan dan perkembangan balita 1-3 tahun, tujuan dari penelitian adalah mengetahui hubungan status gizi dengan pertumbuhan dan perkembangan balita 1-3 tahun di Puskesmas Palapa Kota Bandar Lampung. Hasil dari penelitian terdapat hubungan status gizi dengan pertumbuhan hasil OR yaitu 2,8 dan status gizi dengan perkembangan hasil OR 2,4 pada balita 1-3 tahun.

Tujuan dari penelitian ini adalah untuk melihat hubungan status gizi dan aktivitas bermain baik secara independen maupun dependen dengan keterampilan gerak dasar anak TK. Selain itu, keterbaruan dari penelitian dengan sebelumnya adalah melihat adanya hubungan antara status gizi dan aktivitas bermain dengan keterampilan gerak dasar pada anak TK. Sedangkan penelitian sebelumnya hanya menggunakan satu variable bebas saja.

\section{METODOLOGI}

Metode yang digunakan adalah penelitian kuantitatif bentuk korelasional. Alasan menggunakan metode penelitian ini adalah untuk mendapatkan hubungan antara status gizi dengan keterampilan gerak dasar, aktivitas bermain dengan keterampilan gerak dasar, serta 
status gizi dan aktivitas bermain secara bersama-sama dengan ketemapilan gerak dasar. Gambar 1 merupakan model hipotesis yang diuji dalam penelitian ini.

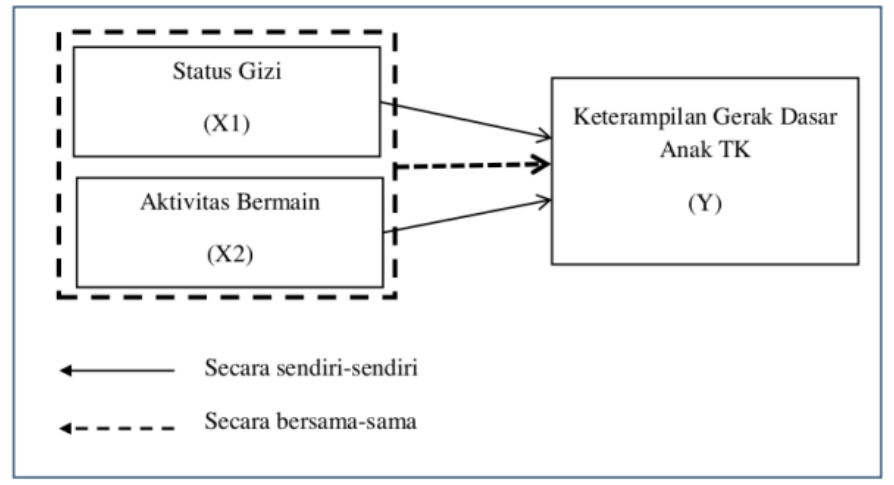

Gambar 1. Model Hipotesis Penelitian

Penelitian dilaksanakan di Taman kanak-kanak Kecamatan Nanggalo Kota Padang. Penarikan sampel dilakukan dengan Teknik Cluster Sampling yang diambil secara simple random sampling. Sampel penelitian yang didapatkan adalah 60 orang usia 5-6 tahun dari 5 kelurahan di TK kecamatan Nanggalo Kota Padang.

Teknik pengumpulan data untuk variable status gizi menggunakan IMT, aktivitas bermain menggunakan angket Skala Likert dan keterampilan gerak dasar menggunakan Tes keterampilan gerak dasar. Teknik analisis data menggunakan korelasi sederhana untuk hipotesis pertama dan kedua, selanjutnya korelasi ganda untuk menguji hipotesis ketiga. Sebelum uji hipotesis terlebih dahulu dilakukan uji persyaratan analisis yaitu uji normalitas, uji regresi. Tabel 1 merupakan instrument yang digunakan peneliti.

Tabel 1. Kategori Status Gizi Pada Usia 6-18 Tahun

\begin{tabular}{lcc}
\hline \multicolumn{1}{c}{ Indeks } & \multicolumn{2}{c}{ Kategori Status Gizi } \\
\cline { 2 - 3 } Indeks Masa & Kategori Status Gizi & Ambang Batas (Z score) \\
Tubuh & Sangat kurus & $<-3$ SD \\
menurut umur & Kurus & -3 SD s/d $<-2$ SD \\
(IMT/U anak & Normal & -2 SD s/d 1 SD \\
usia 5-18 tahun) & Gemuk & $>1$ SD s $/ \mathrm{d} 2$ SD \\
\hline
\end{tabular}

Tabel 2. Kisi-kisi Instrument Aktivitas Bermain

\begin{tabular}{|c|c|c|}
\hline \multirow[t]{2}{*}{ Variabel } & \multicolumn{2}{|c|}{ Kisi Instrumen Aktivitas Bermain } \\
\hline & Subvariabel & Dimensi \\
\hline \multirow{12}{*}{$\begin{array}{l}\text { Aktivitas } \\
\text { Bemain }\end{array}$} & Tipe bermain & Aktif, \\
\hline & & pasif \\
\hline & Jenis aktivitas fisik & Perorangan \\
\hline & & kelompok \\
\hline & Alat aktivitas bermain & Tanpa alat \\
\hline & & Dengan alat \\
\hline & Tempat aktivitas bermain & Indoor \\
\hline & & outdoor \\
\hline & Manfaat aktivitas bermain & menyenangkan \\
\hline & & Kesegaran fisik \\
\hline & Jumlah aktivitas bermain & $\begin{array}{l}\text { Kecenderungan aktivitas fisik dalam } \\
\text { satu hari }\end{array}$ \\
\hline & $\begin{array}{l}\text { Waktu melakukan aktivitas } \\
\text { bermain }\end{array}$ & $\begin{array}{l}\text { Rata-rata aktivitas bermain dalam } \\
\text { satu hari }\end{array}$ \\
\hline
\end{tabular}


Tabel 3. Blanko Tes Keterampilan Gerak Dasar

\begin{tabular}{|c|c|c|c|c|}
\hline \multirow[t]{2}{*}{ Variable } & \multirow[t]{2}{*}{ Indikator } & \multicolumn{3}{|c|}{ Kategori } \\
\hline & & Bs & Bdb & $\mathbf{T b}$ \\
\hline \multirow{11}{*}{$\begin{array}{c}\text { Keterampilan } \\
\text { Gerak Dasar }\end{array}$} & Berlari pada garis lurus & & & \\
\hline & Lari kuda pada garis lurus & & & \\
\hline & Berjalan jinjit ke depan dengan ujung-ujung jari kaki & & & \\
\hline & Melompat ke depan dengan dua kaki & & & \\
\hline & $\begin{array}{l}\text { Meloncat ke samping kiri dan kanan serta ke belakang } \\
\text { dan mendarat dengan dua kaki secara serentak } \\
\text { Meloncat di tempat dengan dua kaki }\end{array}$ & & & \\
\hline & $\begin{array}{l}\text { Meloncat di tempat dengan satu kaki, } 3 \text { kali berurutan } \\
\text { dengan kaki kiri dan kanan secara bergantian } \\
\text { Berdiri dengan satu kaki selama } 10 \text { detik }\end{array}$ & & & \\
\hline & Sikap menyerupai pesawat terbang & & & \\
\hline & $\begin{array}{l}\text { Menaiki tangga dengan kaki bergantuan, tetapi tetap } \\
\text { turun dengan kaki yang sama } \\
\text { Melempar bola dengan satu tangan }\end{array}$ & & & \\
\hline & Menangkap bola dengan satu kaki & & & \\
\hline & Menggelindingkan bola dengan satu tangan & & & \\
\hline & Memantul-mantulkan bola dengan satu tangan & & & \\
\hline
\end{tabular}

\section{HASIL DAN PEMBAHASAN}

Hasil Penelitian

Data penelitian ini terdiri dari hasil tes: Keterampilan Gerak Dasar anak TK di Kecamatan Nanggalo Kota Padang $(Y)$ sebagai variabel terikat, selanjutnya Status Gizi $\left(\mathrm{X}_{1}\right)$, dan Aktivitas Bermain $\left(X_{2}\right)$ sebagai variabel bebas. Berikut ini tabel 4. Deskripsi kesimpulan data penelitian.

Tabel 4. Deskripsi Kesimpulan Data Penelitian

\begin{tabular}{cccc}
\hline Variabel & Status Gizi $\left(\mathbf{X}_{\mathbf{1}}\right)$ & $\begin{array}{c}\text { Hasil Tes } \\
\text { Aktivitas Bermain } \\
\left(\mathbf{X}_{\mathbf{2}}\right)\end{array}$ & $\begin{array}{c}\text { Keterampilan Gerak } \\
\text { Dasar }(\mathbf{Y})\end{array}$ \\
\hline Jumlah & 840,9 & 7078 & 2041 \\
Rata-rata & 14,02 & 118 & 34 \\
SD & 15,70 & 113,00 & 31,00 \\
Min & 10,4 & 90 & 21 \\
Max & 18,0 & 135 & 43 \\
\hline
\end{tabular}

\section{Uji Normalitas Data}

Tabel 5. Rangkuman Hasil Uji Normalitas Data Penelitian

\begin{tabular}{llrrrc}
\hline No & \multicolumn{5}{c}{ Hasil Uji Normalitas } \\
\cline { 2 - 6 } & \multicolumn{1}{c}{ Variabel } & $\mathbf{N}$ & $\mathbf{L}_{\mathbf{o}}$ & $\mathbf{L}_{\text {tab }}$ & Distribusi \\
1 & Status Gizi $\left(\mathrm{X}_{1}\right)$ & 60 & 0,062 & 0,114 & Normal \\
2 & Aktivitas Bermain $\left(\mathrm{X}_{2}\right)$ & 60 & 0,055 & 0,114 & Normal \\
3 & Keterampilan Gerak Dasar $(\mathrm{Y})$ & 60 & 0,076 & 0,114 & Normal \\
\hline
\end{tabular}

Berdasarkan hasil perhitungan uji normalitas pada tabel 5 ditemukan bahwa pengujian normalitas untuk Status Gizi $\left(X_{1}\right)$ diperoleh skor $L_{o}=0,062$ dengan $n=60$, sedangkan $L_{\text {tab }}$ pada taraf pengujian signifikan $\alpha=0,05$ diperoleh 0,114 yang lebih besar dari $L_{o}$ sehingga dapat 
disimpulkan bahwa skor yang diperoleh dari Status Gizi berdistribusi normal. Selanjutnya data hasil tes Aktivitas Bermain $\left(\mathrm{X}_{2}\right)$ berdasarkan uji normalitas diperoleh skor Lo $=0,055$ dengan $n=60$, sedangkan Ltab pada taraf pengujian signifikan $\alpha=0,05$ diperoleh 0,114 yang lebih besar dari Lo sehingga dapat disimpulkan bahwa skor yang diperoleh dari hasil tes ), Aktivitas Bermain normal.

Selanjutnya data hasil tes Keterampilan Gerak Dasar (y) berdasarkan uji normalitas diperoleh skor Lo $=0,076$ dengan $\mathrm{n}=60$, sedangkan Ltab pada taraf pengujian signifikan $\alpha=$ 0,05 diperoleh 0,114 yang lebih besar dari Lo sehingga dapat disimpulkan bahwa skor yang diperoleh dari hasil tes Keterampilan Gerak Dasar normal. Dengan demikian, disimpulkan bahwa semua kelompok data pada penelitian ini diambil dari populasi yang berdistribusi normal sehingga dapat digunakan dan dilanjutkan untuk pengujian hipotesis penelitian.

\section{Analisis Regresi}

Tabel 6. Rangkuman Hasil Pengujian Signifikansi Persamaan Regresi

\begin{tabular}{|c|c|c|c|c|}
\hline \multirow[t]{2}{*}{ No } & \multicolumn{4}{|c|}{ Pengujian Signifikansi Persamaan Regresi } \\
\hline & Jalur Hubungan & $\mathbf{F}_{\text {hitung }}$ & $F_{\text {tabel }}$ & Kesimpulan \\
\hline 1 & $\begin{array}{l}\text { Status Gizi }\left(\mathrm{X}_{1}\right) \text { dengan } \\
\text { Keterampilan Gerak Dasar } \\
(\mathrm{Y})\end{array}$ & 1,66 & 1,87 & Regresi Linear - Signifikan \\
\hline 2 & $\begin{array}{lr}\text { Aktifitas } & \text { Bermain } \quad\left(\mathrm{X}_{2}\right) \\
\text { dengan } & \text { Keterampilan }\end{array}$ & 0,98 & 1,88 & Regresi Linear - Signifikan \\
\hline 3 & $\begin{array}{l}\text { Gerak Dasar }(Y) \\
\text { Status Gizi }\left(X_{1}\right) \text { Aktifitas } \\
\text { Bermain }\left(X_{2}\right) \text { Keterampilan } \\
\text { Gerak Dasar }(Y)\end{array}$ & 14,10 & 3,15 & Regresi Linear - Signifikan \\
\hline
\end{tabular}

Berdasarkan dari tabel 6, Analisis regresi tentang pengaruh variabel Status Gizi (X1) terhadap Variabel Keterampilan Gerak Dasar (Y), diperoleh nilai Fhitung sebesar 1,66, sedangkan nilai Ftabel pada taraf signifikan 0,05 adalah 1,87. Dengan demikian hipotesis diterima pada taraf signifikansi 0,05. Berdasarkan hasil Fhitung $<$ Ftabel, 1,66 $<1,87$. Artinya regresi variabel keterampilan gerak dasar $(\mathrm{Y})$ atas variabel status gizi (X1) adalah signifikan, sehingga dikategorikan memenuhi persyaratan untuk pengujian hipotesis penelitian.

Selanjutnya pada analisis regresi tentang Aktivitas bermain (X2) terhadap Keterampilan gerak dasar $(Y)$, diperoleh nilai Fhitung sebesar 0,98, sedangkan nilai Ftabel pada taraf signifikan 0,05 adalah 1,88. Dengan demikian hipotesis diterima pada taraf signifikansi 0,05. Berdasarkan hasil Fhitung $<$ Ftabel, 0,98<1,88. Artinya regresi Keterampilan gerak dasar $(\mathrm{Y})$ atas variabel Aktivitas bermain $(\mathrm{X} 2)$ adalah signifikan, sehingga dikategorikan memenuhi persyaratan untuk pengujian hipotesis penelitian.

Analisis regresi tentang Status Gizi (X1), Aktivitas bermain (X2) terhadap Keterampilan gerak dasar (Y), diperoleh nilai Fhitung sebesar 14,10, sedangkan nilai Ftabel pada taraf signifikan 0,05 adalah 3,15. Dengan demikian hipotesis diterima pada taraf signifikansi 0,05. Berdasarkan hasil Fhitung $>$ Ftabel, 14,10 >3,15. Artinya regresi Keterampilan gerak dasar $(\mathrm{Y})$ atas variabel Aktivitas bermain $(\mathrm{X} 2)$ dan Analisis regresi tentang Status Gizi (X1) adalah signifikan, sehingga dikategorikan memenuhi persyaratan untuk pengujian hipotesis penelitian.

\section{Status Gizi Memiliki Hubungan Positif dengan Keterampilan Gerak Dasar}

Hasil analisis menunjukkan bahwa status gizi (X1) memiliki hubungan positif dengan Keterampilan Gerak dasar $(Y)$. Nilai persamaan regresinya dapat digambarkan sebagai berikut $\hat{Y}=18,91+1,07 \mathrm{X}$ terhadap Fhitung $(8,17)>$ Ftabel $(4,01)$. Selanjutnya berdasarkan analisis linearitas regresi diperoleh nilai Fhitung $(1,66)<$ Ftabel $(1,87)$. Hal ini menyatakan 
bahwa data berada dalam keadaan linear. Terhadap demikian hipotesis yang diajukan (Ha) dapat diterima.

Tabel 7. Daftar ANAVA Regresi Linear $\hat{Y}=18,91+1,07$

\begin{tabular}{lllllll}
\hline Sumber Variasi & \multicolumn{1}{c}{ Dk } & \multicolumn{1}{c}{ JK } & \multicolumn{1}{c}{ KT } & \multicolumn{1}{c}{ Fh } & Ft $\mathbf{a}=\mathbf{0 . 0 5}$ & Kesimpulan \\
\hline Total & 60 & 70929 & - & - & & \\
Koefisien (a) & 1 & 69428,01 & - & 8,17 & 4,01 & Regresi \\
Regresi (b/a) & 1 & 185,52 & 185,52 & & & signifikan \\
Sisa & 58 & 1315,47 & 22,68 & & & (berarti) \\
Tuna Cocok & 30 & 842,97 & 28,09 & 1,66 & 1,87 & Regresi Linear \\
Galat & 28 & 472,50 & 16,87 & & & \\
\hline
\end{tabular}

Selanjutnya pada tabel 7, analisis korelasi data penelitian diperoleh koefisien korelasi Status Gizi terhadap Keterampilan gerak dasar $r_{\text {hitung }}(0,352)$ dengan $t_{\text {hitung }}=1,93>t_{\text {tabel }}=0,116$ menyatakan bahwa terdapat hubungan positif $X_{I}$ terhadap variabel $Y$ yang dapat dilihat pada tabel 8 .

Tabel 8. Analisis Koefisien Korelasi Status Gizi dengan Keterampilan Gerak Dasar

\begin{tabular}{cccccc}
\hline $\begin{array}{c}\text { Korelasi } \\
\text { Antara }\end{array}$ & $\begin{array}{c}\text { Koefisien } \\
\text { Korelasi }\end{array}$ & $\begin{array}{c}\text { Koefisien } \\
\text { Determinasi }\end{array}$ & $\mathbf{t}_{\text {hitung }}$ & $\begin{array}{c}\mathbf{t}_{\text {tabel }} \\
\mathbf{a}=\mathbf{0 , 0 5}\end{array}$ & Kesimpulan \\
\hline $\mathbf{X}_{\mathbf{1}}$ terhadap $\mathbf{Y}$ & 0,352 & $12,45 \%$ & 1,93 & 0,116 & Hubungan Positif \\
\hline
\end{tabular}

\section{Aktivitas Bermain Memiliki Hubungan Positif dengan Keterampilan Gerak Dasar}

Hasil analisis menunjukkan bahwa Aktivitas Bermain $\left(X_{2}\right)$ memiliki hubungan positif dengan Keterampilan Gerak Dasar. Nilai persamaan regresinya dapat digambarkan sebagai berikut $\hat{Y}=2,29+0,26 X$ terhadap $F_{\text {hitung }} 19,79>F_{\text {tabel }} 4,01$. Selanjutnya berdasarkan analisis linearitas regresi diperoleh nilai $\mathrm{F}_{\text {hitung }} 0,98<\mathrm{F}_{\text {tabel }} 1,88$. Hal ini menyatakan bahwa data berada dalam keadaan linear.

Tabel 9. Daftar ANAVA Regresi Linear $\hat{Y}=2,29+0,26 X$

\begin{tabular}{ccccccc}
\hline Sumber Variasi & DK & JK & KT & Fh & $\begin{array}{c}\text { Ft a } \\
\mathbf{= 0 , 0 5}\end{array}$ & Kesimpulan \\
\hline Total & 60 & 70929 & - & - & & \\
Koefisien (a) & 1 & 69428,01 & - & - & & Regresi signifikan \\
Regresi (b/a) & 1 & 381,94 & 381,94 & 19,79 & 4,01 & (berarti) \\
$\quad$ Sisa & 58 & 1119,05 & 19,29 & & & Regresi Linear \\
Tuna Cocok & 26 & 496,97 & 19,11 & 0,98 & 1,88 & \\
$\quad$ Galat & 42 & 622,08 & 14,81 & & &
\end{tabular}

Selanjutnya pada tabel 9, analisis korelasi data penelitian diperoleh koefisien korelasi Aktivitas Bermain dengan Keterampilan Gerak Dasar $r_{\text {hitung }}(0,512)$ terhadap $t_{\text {hitung }}=4,52>t_{\text {tabel }}$ $=0,116$ menyatakan bahwa terdapat hubungan positif variabel $\mathrm{X}_{2}$ dengan variabel $\mathrm{Y}$ dapat dilihat pada tabel 10 .

Tabel 10. Analisis Korelasi $X_{2}$ dengan $Y$

\begin{tabular}{cccccc}
\hline $\begin{array}{c}\text { Korelasi } \\
\text { Antara }\end{array}$ & $\begin{array}{c}\text { Koefisien } \\
\text { Korelasi }\end{array}$ & $\begin{array}{c}\text { Koefisien } \\
\text { Determinasi }\end{array}$ & $t_{\text {hitung }}$ & $\begin{array}{c}t_{\text {tabel }} \\
\mathrm{a}=0,05\end{array}$ & Kesimpulan \\
\hline $\mathbf{X}_{\mathbf{2}}$ terhadap $\mathbf{Y}$ & 0,512 & $26,21 \%$ & 4,52 & 0,116 & Hubungan Positif \\
\hline
\end{tabular}




\section{Status Gizi dan Aktivitas Bermain Secara Bersama-sama Memiliki Hubungan Positif dengan Keterampilan Gerak Dasar}

Status Gizi dan Aktivitas Bermain secara bersama-sama memiliki hubungan positif dengan Keterampilan Gerak Dasar. Pengujian hipotesis ketiga ini dilakukan menggunakan analisis regresi ganda dan korelasi ganda. Berdasarkan hasil perhitungan menghasilkan nilai $\mathrm{a}=-5,92, \mathrm{~b}_{1}=0,83, \mathrm{~b}_{2}=0,24$ terhadap demikian persamaan regresi $\mathrm{Y}$ atas $\mathrm{X}_{1}, \mathrm{X}_{2}$, adalah $\hat{\mathrm{Y}}=-$ $5,92+0,83 X_{1}-0,24 X_{2}$. Untuk menguji signifikansi persamaan regresi ganda terhadap variabel Y digunakan tabel 11 ANAVA berikut.

Tabel 11. ANAVA Pengujian Signifikansi Regresi Ganda $\hat{Y}=32,35+0,19 X_{1}-1,74 X_{2}+0,27 X_{3}$

\begin{tabular}{cccc}
\hline Sumber Variasi & $\mathrm{JK}$ & $\mathrm{F}_{\text {hitung }}$ & $\mathrm{F}_{\text {tabel }} \mathrm{a}=0,05$ \\
\hline Regresi & 496,74 & 14,10 & 3,15 \\
Sisa & 1004,26 & & \\
\hline
\end{tabular}

Uji signifikansi regresi ganda pada tabel 11, diperoleh $F_{\text {hitung }} 14,10>F_{\text {tabel }} 3,15$. Artinya persamaan regresi ganda $\hat{Y}=-5,92+0,83 X_{1}-0,24 X_{2}$ adalah signifikan. Dengan demikian maka dapat disimpulkan bahwa Status Gizi, Aktivitas Bermain, secara bersama-sama memiliki hubungan positif dengan Keterampilan Gerak Dasar.

Selanjutnya berdasarkan kekuatan hubungan sebesar 0,169 kemudian terhadap nilai koefisien korelasi ini dilakukan pengujian signifikansi korelasi $\mathrm{X}_{1}, \mathrm{X}_{2}$ dengan $\mathrm{Y}$ menggunakan distribusi F hasil perhitungan adalah pada tabel 12 berikut:

Tabel 12. Uji Signifikansi Korelasi $X_{1}, X_{2}$ terhadap $Y$

\begin{tabular}{cccccc}
\hline $\begin{array}{c}\text { Korelasi } \\
\text { antara }\end{array}$ & $\begin{array}{c}\text { Koefisien } \\
\text { Korelasi }\end{array}$ & $\begin{array}{c}\text { Koefisien } \\
\text { Determinasi }\end{array}$ & $\mathbf{F}_{\text {hitung }}$ & $\begin{array}{c}\mathbf{F}_{\text {tabel }} \\
\mathbf{\alpha}=\mathbf{0 , 0 5}\end{array}$ & Kesimpulan \\
\hline $\begin{array}{c}\text { X1, X2 } \\
\text { terhadap Y }\end{array}$ & 0,692 & $47,89 \%$ & 1,305 & 0,116 & $\begin{array}{c}\text { Hubungan } \\
\text { Positif }\end{array}$ \\
\hline
\end{tabular}

Berdasarkan uji keberartian korelasi antara pasangan skor Status Gizi (X1),Aktifitas Bermain(X2) dengan Keterampilan Gerak Dasar (Y) sebagaimana terlihat pada tabel di atas diperoleh Fhitung $(1,305)>$ Ftabel $(0,116$ pada taraf signifikansi $\alpha=0.05$. Untuk melihat besarnya hubungan, Status Gizi dan Aktifitas Bermain secara bersama-sama dengan Keterampilan Gerak Dasar dicari melalui koefisien determinasi r2 $=0,6922$ yang hasilnya adalah 47,89 .

Artinya bahwa Status Gizi dan Aktifitas Bermain secara bersama-sama dengan Keterampilan Gerak Dasar memiliki hubungan positif sebesar 47,89\% terhadap Keterampilan Gerak Dasar. Sisanya 52,11\% ditentukan oleh variabel lain yang tidak diperhitungkan dalam penelitian ini. Berdasarkan hasil pengujian di atas, maka dapat disimpulkan Status Gizi dan Aktifitas Bermain secara bersama-sama memiliki hubungan positif terhadap Keterampilan Gerak Dasar.

\section{Pembahasan}

Hubungan Positif antara Status Gizi dengan Keterampilan Gerak Dasar Anak TK di Kecamatan Nanggalo Kota Padang

Pada perhitungan hasil analisis. Status Gizi memberikan hubungan yang Positif terhadap Keterampilan gerak dasar Anak TK di Kecamatan Nanggalo Kota Padang. terlihat dari hasil analisis nilai $t_{\text {hitung }}$ lebih besar dari nilai $t_{\text {tabel, }}, 1,93>0,116$ maka dalam hal ini $\mathrm{H}_{\mathrm{a}}$ diterima dan $\mathrm{H}_{0}$ ditolak pada taraf Positif $\mathrm{a}=0,05$. Dengan demikian hipotesis Pertama diterima kebenarannya, besarnya \% hubungan yang diberikan dapat dilihat dengan rumus $\left(r^{2} \times 100 \%=0,352^{2} \times 100 \%\right)$ yaitu $12,45 \%$, hal ini berarti terbukti hipotesis sebelumnya dapat 
diterima. Hasil pengujian tersebut sesuai dengan kajian teori, kerangka teoretik serta hipotesis yang diajukan dalam penelitian ini.

Dimana Status gizi merupakan keadaan kesehatan tubuh sekelompok orang yang diakibatkan oleh konsumsi, penyerapan dan penggunaan zat gizi makanan. Anak yang mempunyai Status gizi yang baik tentu pertumbuhan dan perkembangannya akan berjalan seimbang dan sehat. Bila anak sudah sehat tentu dia akan dapat melaksanakan tugas seharihari dengan baik (belajar dan bermain). Status gizi selama masa sekolah merupakan faktor penentu utama gizi dan kesehatan dalam kehidupan, banyak penelitian yang ditemukan menyatakan kekurangan gizi dan anemia memiliki dampak buruk terhadap kinerja dan aktivitas sehari-hari yang akan menurun.

Berdasarkan hasil penelitian yang dilakukan bahwa ada hubungan positif antara status gizi dengan keterampilan gerak dasar anak TK. Hal ini Sejalan dengan penelitian Antoni \& Bakhtiar (2019) bahwa data status gizi yang didapatkan pada nilai rata-rata adalah 20,1 dengan nilai tertinggi 37,7 dan nilai terendah 16,1. Status gizi anak bisa lebih baik jika orang tua memahami tentang zat gizi yang mampu mempengaruhi gerak dasar lokomotor anak. Setelah itu, terdapat hubungan signifikan antara status gizi terhadap keterampilan dasar lokomotor anak. Hasil yang didapatkan adalah Ho ditolak dan Ha memperoleh nilai t hitung $2,398>\mathrm{t}$ tabel 2,048.

Berbeda dengan hasil penelitian Prisyana \& Nurhayat (2019) menunjukkan bahwa tidak ada hubungan signifikan status gizi dengan kemampuan motoric anak kelas atas di SDN Betiting. Tidak ada hubungan yang signifikan antara aktivitas fisik dengan kemampuan motorik anak. Kemudian tidak ada hubungan yang signifikan antara status gizi dan aktivitas motorik dengan kemampuan motorik anak, sehingga hasil yang didapatkan anatara status gizi an aktivitas fisik terhadap kemampuan motoric anak adalah 8,9\%.

\section{Hubungan Positif antara Aktivitas Bermain dengan Keterampilan Gerak Dasar Anak TK di Kecamatan Nanggalo Kota Padang}

Pada Perhitungan hasil analisis, aktivitas bermain memberikan hubungan yang Positif terhadap Keterampilan gerak dasar Anak TK di Kecamatan Nanggalo Kota Padang. Hasil analisis terlihat nilai $\mathrm{t}_{\text {titung }}$ lebih besar dari nilai $\mathrm{t}_{\text {tabel, }}, 4,52>0,116$ maka dalam hal ini $\mathrm{H}_{\mathrm{a}}$ diterima dan $\mathrm{H}_{0}$ ditolak pada taraf Positif $a=0,05$. Dengan demikian hipotesis kedua diterima kebenarannya, besarnya \% hubungan yang diberikan dapat dilihat dengan rumus $\left(r^{2} \times 100 \%\right.$ $=0,512^{2} \times 100 \%$ ) yaitu $26,21 \%$. hal ini berarti terbukti hipotesis sebelumnya dapat diterima. Hasil pengujian tersebut sesuai dengan kajian teori, kerangka teoritik serta hipotesis yang diajukan dalam penelitian ini.

Perkembangan pada anak usia dini mencakup perkembangan fisik dan motorik, kognitif, sosial emosional dan bahasa. Masa Taman Kanak-kanak (TK) merupakan masa pertumbuhan yang paling hebat dan sekaligus paling sibuk. Pada masa ini anak sudah memiliki keterampilan dan keterampilan walaupun belum sempurna. Usia anak pada masa ini merupakan fase fundamental yang akan menentukan kehidupannya di masa datang. Oleh sebab itu, sebagai orangtua dan pendidik harus memahami perkembangan anak usia dini khususnya perkembangan fisik dan motorik. Namun, seperti penelitian yang dilakukan oleh Fitria \& Rohita (2019) ditemukan bahwa terdapat 15\% guru yang belum mengetahui pentingnya aktivitas bermain yang berkaitan dengan keterampilan gerak dasar melalui gerakan morotik. Setelah dilakukan penelitian $75 \%$ guru TK mengetahui betapa pentingnya tujuan menstimulasi gerak dasar anak dengan melalukan aktivitas bermain.

Aktivitas bermain merupakan hal penting bagi anak karena mempengaruhi seluruh emosi, perasaan, dan pikirannya. Pendidikan di TK dilaksanakan dengan prinsip "Bermain sambil belajar, atau belajar seraya bermain". Berdasarkan beberapa hasil penelitian menunjukkan bahwa aktivitas bermain dapat meningkatkan aspek-aspek kemampuan motorik kasar anak termasuk keterampilan gerak dasarnya (Kusumaningtyas, 2016; Novitasari et al., 2019; Oedjoe \& Bunga, 2016). Sesuai dengan perkembangannya, oleh sebab 
itu diharapkan seorang pendidik yang kreatif dan inovatif agar anak bisa merasa senang, tenang, aman dan nyaman selama dalam proses belajar mengajar.

\section{Hubungan Positif antara Status Gizi dan Aktivitas Bermain Secara Bersama-sama dengan Keterampilan Gerak Dasar Anak TK di Kecamatan Nanggalo Kota Padang}

Pada Perhitungan hasil analisis, terlihat Status Gizi dan Aktivitas Bermain secara bersama-sama memberikan hubungan Positif terhadap Keterampilan Gerak Dasar anak TK. Selanjutnya Uji korelasi ganda dengan 2 prediktor yang dilakukan pada $X_{1}$, dan $X_{2}$, terhadap $Y$, hasil analisis di atas terlihat nilai $t_{\text {hitung }}$ lebih besar dari nilai $t_{\text {tabel, }}, 1,305>0,116$ maka dalam hal ini $\mathrm{H}_{a}$ diterima dan $\mathrm{H}_{0}$ ditolak pada taraf Positif $\alpha=0,05$. Dengan demikian hipotesis ketiga diterima kebenarannya, besarnya \% hubungan yang diberikan dapat dilihat dengan rumus 0,692²x $100 \%$ yaitu $47,89 \%$. Hal ini berarti terbukti hipotesis sebelumnya dapat diterima. Hasil pengujian tersebut sesuai dengan kajian teori, kerangka teoritik serta hipotesis yang diajukan dalam penelitian ini.

Perkembangan motorik dasar yang erat kaitannya dengan perkembangan pusat motorik di otak. Keterampilan motorik berkembang sejalan dengan kematangan otak dan syaraf. Oleh sebab itu, setiap gerakan yang dilakukan anak sesederhana apapun, sebenarnya merupakan hasil pola interaksi yang kompleks dari berbagai bagian dan sistem dalam tubuh yang dikontrol otak. Maka dari itu otaklah yang berfungsi sebagai bagian dari susunan syaraf yang mengatur dan mengontrol semua aktivitas fisik dan mental seseorang, perkembangan motorik terbagi atas motorik halus dan motorik kasar. Aktivitas bermain merupakan bagian dari aktivitas fisik. Melalui aktivitas bermain, seseorang anak melakukan berbagai kegiatan spontan di lingkungannya dengan menggunakan imajinasi, penampilan, seluruh perasaan, tangan, dan seluruh badan dengan melibatkan fisik atau jasmaninya (Syampurma, 2018). Sedangkan status gizi juga mempengaruhi tubuh seseorang. Seseorang yang memiliki status gizi yang normal maka dapat melakukan aktivitas fisik berupa gerakan dasar (Antoni \& Bakhtiar, 2019).

Berdasarkan hasil penelitian terdapat hubungan positif antara status gizi dengan keterampilan gerak dasar anak, serta terdapat hubungan positif antara aktivitas bermain dan status gizi dengan keterampilan gerak dasar anak di TK Kecamatan Nanggalo Kota Padang. Hasil penelitian yang dilakukan Hairunis et al., (2018) menunjukkan bahwa terdapat hubungan antara status gizi dengan perkembangan anak, perkembangan yang dimaksudkan adalah perkembangan motoric anak, bahasa, social, serta kemandirian anak di masa yang akan datang. Jika status gizi atau kesehatan anak baik maka anak bersemangat melakukan aktivitas bermain atau fisik, sehingga dapat mengembangkan keterampilan gerak dasar anak (Munif et al., 2019).

\section{SIMPULAN}

Berdasarkan penelitian yang dilakukan bahwa terdapat hubungan positif antara Status Gizi dengan Keterampilan Gerak Dasar Anak TK di Kecamatan Nanggalo Kota Padang sebesar $12,45 \%$. Terdapat hubungan positif antara Aktivitas Bermain dengan Keterampilan Gerak Dasar Anak TK di Kecamatan Nanggalo Kota Padang sebesar 26,21\%. Terdapat hubungan positif antara Status Gizi dan Aktivitas Bermain secara bersama-sama dengan Keterampilan Gerak Dasar Anak TK di Kecamatan Nanggalo Kota Padang sebesar 47,89\%.

\section{UCAPAN TERIMAKASIH}

Peneliti ucapkan terima kasih kepada pihak-pihak yang terkait yang telah membantu menyelesaikan artikel penelitian ini, terutama TK di Kecamatan Nanggalo Kota Padang.

\section{DAFTAR PUSTAKA}

Agustini, I. P., Tomi, A., \& Sudjana, I. N. (2016). Metode Bermain Dalam Pembelajaran Pendidikan Jasmani Siswa Kelas III C SDN Krian III Kabupaten Sidoarjo. Pendidikan 
Jasmani, 26(2), 229-237. https:/ / doi.org/10.17977/pj.v26i2.7502.g3422

Alderman, H., Behrman, J. R., Lavy, V., \& Menon, R. (1999). Child nutrition, child health, and school enrollment: a longitudinal analysis. The World Bank.

Anisa Herdiyana, G. P. W. P. (2016). Pembelajaran Pendidikan Jasmani Yang Mengacu Pada Pembiasaan Sikap Fair Play Dan Kepercayaan Pada Peserta Didik. Jurnal Olahraga Prestasi, 12(1), 115109. https:/ / doi.org/10.21831/jorpres.v12i1.9498

Antoni, R., \& Bakhtiar, S. (2019). Hubungan Status Gizi Terhadap Keterampilan Gerak Dasar Lokomotor di Sekolah Dasar. Jurnal JPDO, 2(8), 21-27.

Ayuni, D., \& Setiawati, F. A. (2019). "Kebun Buah" Learning Media for Early Childhood Counting Ability Despa. Jurnal Obsesi : Jurnal Pendidikan Anak Usia Dini, 3(1), 1-9. https:// doi.org/10.31004/obsesi.v3i1.128

Baykal, B., Donar, Y. O., Bilge, S., \& Sınağ, A. (n.d.). Gallic acid and ammonium fluoride functionalized TiO2 nanoparticles.

Bhutta, Z. A., Das, J. K., Rizvi, A., Gaffey, M. F., Walker, N., Horton, S., Webb, P., Lartey, A., Black, R. E., \& Group, T. L. N. I. R. (2013). Evidence-based interventions for improvement of maternal and child nutrition: what can be done and at what cost? The lancet, 382(9890), 452-477.

Chatterjee, D. S., Biswas, S. J., \& Adhikary, D. S. R. (2014). A Study on the Relationship between Nutrition Status and Physical Fitness of School Boys. IOSR Journal of Sports and Physical Education, 1(5), 46-50.

Chen, J.-X., Xue, H.-J., Ye, W.-C., Fang, B.-H., Liu, Y.-H., Yuan, S.-H., Yu, P., \& Wang, Y.-Q. (2009). Activity of andrographolide and its derivatives against influenza virus in vivo and in vitro. Biological and Pharmaceutical Bulletin, 32(8), 1385-1391.

Fitria, N., \& Rohita, R. (2019). Pemetaan Pengetahuan Guru TK tentang Keterampilan Gerak Dasar Anak TK. Jurnal Al-Azhar Indonesia Seri Humaniora, 5(2), 76. https:// doi.org/10.36722/sh.v5i2.346

Gonçalves, P. A. D., Stenger, N., Cox, J. D., Mortensen, N. A., \& Xiao, S. (2020). Strong lightmatter interactions enabled by polaritons in atomically thin materials. Advanced Optical Materials, 8(5), 1901473.

Grantham-McGregor, S. M., Fernald, L. C., Kagawa, R. M., \& Walker, S. (2014). Effects of integrated child development and nutrition interventions on child development and nutritional status. Ann NY Acad Sci, 1308(1), 11-32.

Hairunis, M. N., Salimo, H., \& Dewi, Y. L. R. (2018). Hubungan Status Gizi dan Stimulasi Tumbuh Kembang dengan Perkembangan Balita. Sari Pediatri, 20(3), 146. https:// doi.org/10.14238/sp20.3.2018.146-51

Hands, B., \& Martin, M. (2003). Fundamental Movement Skills: Children's Perspectives. Australasian Journal of Early Childhood, 28(4), 47-52. https:// doi.org/10.1177/183693910302800409

Herrera, F., \& Owrutsky, J. (2020). Molecular polaritons for controlling chemistry with quantum optics. The Journal of Chemical Physics, 152(10). https:// doi.org/10.1063/1.5136320

Jhony, H., \& Putra, G. I. (2019). Mengembangkan Keterampilan Gerak Dasar Manipulatif bagi Anak Melalui Permainan Olahraga di Taman Kanak-Kanak. Jurnal Muara Pendidikan, $4(2), 438-444$.

Johnson, J. L., Rudisill, M. E., Hastie, P., Wadsworth, D., Strunk, K., Venezia, A., Sassi, J., Morris, M., \& Merritt, M. (2019). Changes in Fundamental Motor-Skill Performance Following a Nine-Month Mastery Motivational Climate Intervention. Research Quarterly for Exercise and Sport, 90(4), 517-526. https:/ / doi.org/10.1080/02701367.2019.1628909

Kusumaningtyas, L. E. (2016). Bermain Dalam Rangka Mengembangkan Motorik Pada Anak Usia Dini. Jurnal INDRIA (Jurnal Ilmiah Pendidikan Prasekolah dan Sekolah Awal), 1(1), 3241. https:/ / doi.org/10.24269/jin.v1n1.2016.pp32-41 
Lillard, A. S., Hopkins, E. J., Dore, R. A., Palmquist, C. M., Lerner, M. D., \& Smith, E. D. (2013). Concepts and theories, methods and reasons: Why do the children (pretend) play? Reply to Weisberg, Hirsh-Pasek, and Golinkoff (2013); Bergen (2013); and Walker and Gopnik (2013).

Lubans, D. R., Morgan, P. J., Cliff, D. P., Barnett, L. M., \& Okely, A. D. (2010). Fundamental Movement Skills in Children and Adolescents. Sports Medicine, 40(12), 1019-1035. https://doi.org/10.2165/11536850-000000000-00000

Marinšek, M., \& Denac, O. (2020). The Effects of an Integrated Programme on Developing Fundamental Movement Skills and Rhythmic Abilities in Early Childhood. Early Childhood Education Journal, 48(6), 751-758. https:/ / doi.org/10.1007/s10643-020-010428

Munif, Pudyaningtyas, A. R., \& Parwatiningsih, S. A. (2019). Kompetensi Motorik Anak Usia Dini: Keterkaitannya Dengan Kognitif, Afektif, dan Kesehatan. JIV-Jurnal Ilmiah Visi, 14(2), 123-132. https:// doi.org/10.21009/JIV.1402.5

Novitasari, R., Nasirun, M., \& D., D. (2019). Meningkatkan Kemampuan Motorik Kasar Anak Melalui Bermain Dengan Media Hulahoop Pada Anak Kelompok B PAUD AlSyafaqoh Kabupaten Rejang Lebong. Jurnal Ilmiah POTENSIA, 4(1), 6-12. https://doi.org/10.33369/jip.4.1.6-12

Obrusnikova, I., \& Cavalier, A. (2018). An Evaluation of Videomodeling on Fundamental Motor Skill Performance of Preschool Children. Early Childhood Education Journal, 46(3), 287-299. https://doi.org/10.1007/s10643-017-0861-y

Oedjoe, M. R., \& Bunga, B. N. (2016). Meningkatkan Kemampuan Motorik Kasar Melalui Permainan Tradisional "Sikodoka" Bagi Anak Usia Dini Berlatar Belakang Tuna Grahita Improving Gross Motor Skills Through Traditional Game "Sikodoka "in Early Childhood With Intellectual Disability. 11(2), 73-80.

Prisyana, D. I., \& Nurhayat, F. (2019). Hubungan Antara Status Gizi dan Aktivitas Fisik Dengan Kemampuan Motorik Pada Siswa Kelas Atas Di SDN Betiting Gresik. Jurnal Pendidikan Olahraga dan Kesehatan, 7(2), 315-320.

Reinke, N. B., Kynn, M., \& Parkinson, A. L. (2020). Conceptual understanding of osmosis and diffusion by Australian first-year biology students. International Journal of Innovation in Science and Mathematics Education (formerly CAL-laborate International), 27(9).

Rozalena, R., \& Kristiawan, M. (2017). Pengelolaan Pembelajaran Paud Dalam Mengembangkan Potensi Anak Usia Dini. JMKSP (Jurnal Manajemen, Kepemimpinan, dan Supervisi Pendidikan), 2(1), 76-86. https:// doi.org/10.31851/jmksp.v2i1.1155

Setiawati, S., Yani, E. R., \& Rachmawati, M. (2020). Hubungan status gizi dengan pertumbuhan dan perkembangan balita 1-3 tahun. Holistik Jurnal Kesehatan, 14(1), 8895. https:// doi.org/10.33024/hjk.v14i1.1903

Surya, Y. F. (2017). Penggunaan Model dan Pendekatan Pembelajaran Pendidikan Karakter Abad 21 pada Anak Usia Dini. Jurnal Obsesi : Journal of Early Childhood Education, 1(1), 52. https:// doi.org/10.31004/obsesi.v1i1.48

Syampurma, H. (2018). Hubungan Aktivitas Fisik dengan Kesegaran Jasmani pada Siswa Sekolah Menengah Pertama Bertaraf Internasional Kota Padang. Sport Science, 18(1), 55-65. https://doi.org/10.24036/jss.v18i1.43

Wijayanto, Y., \& Muhammad, H. N. (2014). Hubungan Anatara Tingkat Kesegaran Jasmani dengan Keterampilan Motorik (Kelincahan) Di SMP Negeri satu Atap Jabon (Studi Pada Kelas VII). Jurnal Pendidikan Olahraga dan Kesehatan Volume, 2(2), 345-349. 